\title{
Penerapan Asas Pemisahan Horizontal Pada Hak Pakai Bagi Orang Asing di Indonesia
}

\author{
Alfian Adam Naafiu dan Nian Qisthi Kristalin \\ alfianadamnaafiu@gmail.com \\ Universitas Airlangga
}

Kata Kunci:
Horizontal
Scheiding; Hak
Pakai; Foreigners.

\begin{abstract}
Horizontal Scheiding is the principle that adopted from customary law, used in the establishment of Undang-Undang Number 5 of 1960 on Peraturan Dasar Pokok-Pokok Agraria as well as related legislation. Horizontal Scheiding provides legal protection for owner of Hak atas Tanah with respect to buildings and/or objects thereon. The creation of laws and regulations that regulate matters related to the ownership of a residential or residential house by foreigners who are domiciled in Indonesia, provides an opportunity for foreigners to be able to have Hak atas Tanah in Indonesia, namely Hak Pakai as stipulated in the Peraturan Pemerintah Republik Indonesia Number 18 of 2021 concerning Hak Pengelolaan, Hak Atas Tanah, Satuan Rumah Susun, dan Pendaftaran Tanah.In the case of foreigners who can own Hak atas Tanah with the status of Hak Pakai, if the Hak Pakai expire then foreigners are required to return the land according to the status of Hak atas Tanah that they are occupy, including it can lead to the demolition of buildings built on the Hak atas Tanah that have been obtained with or without being able to ask for compensation unless agreed in the land use agreement.
\end{abstract}

Keywords:

Asas Pemisahan Horizontal; Hak Pakai; Orang Asing.

\section{Abstrak}

Asas Pemisahan Horizontal merupakan asas yang diserap dari hukum adat yang digunakan dalam pembentukan Undang - Undang Nomor 5 Tahun 1960 tentang Peraturan Dasar Pokok-pokok Agraria serta Peraturan Perundangundangan terkait. Asas Pemisahan Horizontal memberikan perlindungan hukum bagi pemegang hak atas tanah terhadap kaitannya dengan bangunan dan/atau benda-benda diatasnya. Lahirnya Peraturan perundang-undangan yang mengatur hal-hal terkait dengan pemilikan rumah tempat tinggal atau hunian oleh orang asing yang berkedudukan di Indonesia, memberikan kesempatan bagi orang asing untuk dapat memiliki hak atas tanah di Indonesia yakni Hak Pakai sebagaimana ketentuan dalam Peraturan Pemerintah Republik Indonesia Nomor 18 Tahun 2021 tentang Hak Pengelolaan, Hak Atas Tanah, Satuan Rumah Susun, dan Pendaftaran Tanah.Dalam hal orang asing yang dapat memiliki hak atas tanah dengan status tanah Hak Pakai, apabila Hak Pakai berakhir maka bagi orang asing wajib mengembaikan tanahnya sebagaimana status hak atas tanah yang ditumpangi tersebut termasuk dapat mengarah pada pembongkaran bangunan yang dibangun diatas hak atas tanah yang diperoleh, dengan atau tanpa dapat memohonkan ganti kerugian kecuali diperjanjikan dalam perjanjian penggunaan tanah.

Copyright ( 2021 Alfian Adam Naafiu dan Nian Qisthi Kristalin Published in Media Iuris. Published by Universitas Airlangga, Magister Ilmu Hukum. 
Alfian Adam: Penerapan Asas Pemisahan...

\section{Pendahuluan}

Tanah dijadikan tolok ukur kepemilikan harta seseorang. Itulah mengapa keberadaan tanah khususnya kepemilikan atas tanah perlu diatur dan dipositifkan melalui peraturan perundang-undangan. Dalam Undang-Undang Dasar Negara Republik Indonesia Tahun 1945' (selanjutnya disebut UUD NRI '45), Pasal 33 ayat (3) yang mengatur "Bumi dan air dan kekayaan alam yang terkandung didalamnya dikuasai oleh negara dan dipergunakan untuk sebesar-besarnya kemakmuran rakyat" yang kemudian ditindak lanjuti pada tanggal 24 September 1960 lahir Undang-Undang Republik Indonesia Nomor 5 Tahun 1960 tentang Peraturan Dasar Pokok-Pokok Agraria² (selanjutnya disebut UUPA) merupakan perwujudan perlindungan hukum bagi rakyat indonesia atas penggunaan dan pemanfaatan tanah agar negara dapat menguasai tanah dan mimpi buruk atas perbuatan penjajah pada era kolonial tidak dapat terulang kembali.

Indonesia memiliki ironi sejarah, selama kurang lebih 350 tahun Indonesia diduduki oleh penjajah yang hanya memanfaatkan Indonesia sebagai pusat perdagangan guna kemajuan negara penjajah. Awal mula masuknya penjajah di negara Indonesia tidak bertujuan untuk mengambil wilayah melainkan hanya untuk berdagang. VOC (Verenigde Oost Indishche Compagnie) adalah perusahaan dagang Belanda yang awalnya dipimpin oleh Jenderal Pieter Both (1602) hingga kepemimpinan Jenderal Pieter Gerardus Van Overstraten (1799) ${ }^{3}$ , mengawali kedatangan bangsa asing ke Indonesia yang bertujuan melakukan kegiatan perdagangan dalam bidang rempah-rempah. Hal ini dilakukan karena Indonesia merupakan negara yang kaya akan hasil bumi salah satunya rempahrempah yang saat itu menjadi kebutuhan yang paling dibutuhkan oleh masyarakat dunia. Kehadiran VOC di Indonesia tidak serta merta menghapuskan hak-hak

${ }^{1}$ Undang-Undang Dasar Negara Republik Indonesia 1945.

${ }^{2}$ Undang-Undang Republik Indonesia Nomor 5 Tahun 1960 tentang Peraturan Dasar PokokPokok Agraria, Lembaran Negara Republik Indonesia Nomor 104 Tahun 1960, Tambahan Lembaran Negara Republik Indonesia Nomor 2043.

${ }^{3}$ Wikipedia bahasa Indonesia, 'Daftar Gubernur-Jenderal Hindia Belanda', (Wikipedia bahasa Indonesia, 7 Juni 2019), <https://id.wikipedia.org/wiki/Daftar_Gubernur-Jenderal_Hindia_ Belanda> diakses pada 26 Juni 2019. 
atas tanah dan hak-hak yang terkait atas hak atas tanah yang dimiliki oleh rakyat dan raja-raja Indonesia akan tetapi terdapat kebijakan-kebijakan yang timbul dan bersifat menindas rakyat Indonesia antara lain yaitu: ${ }^{4}$

1. Contingenten, yaitu pajak atas hasil tanah pertanian yang diserahkan kepada penguasa kolonial (kompeni). Petani harus menyerahkan sebagian dari hasil pertaniannya kepada kompeni tanpa dibayar sepeser pun.

2. Verplichte leveranten, yaitu suatu bentuk ketentuan yang diputuskan oleh kompeni dengan para raja tentang kewajiban menyerahkan seluruh hasil panen dengan pembayaran yang harganya juga sudah ditetapkan secara sepihak. Dengan ketentuan ini, rakyat tani benar-benar tidak bisa berbuat apa-apa. Mereka tidak berkuasa atas apa yang mereka hasilkan.

3. Roerendiensten. kebijakan ini dikenal dengan nama kerja rodi, yang dibebankan kepada rakyat Indonesia yang tidak mempunyai tanah pertanian.

Keberadaan VOC yang cukup lama tidak membuat kedudukannya bertahan di Indonesia, dikarenakan Belanda mengalami kekalahan perang. Sehingga, Belanda membutuhkan dana untuk membangun kembali negaranya dan membayar utang-utang atas kekalahan perang yang memaksa VOC untuk menyerahkan penguasaan atas wilayah Indonesia kepada pemerintah Belanda.

Pada tahun 1800 wilayah Indonesia yang dikuasai oleh pemerintahan HindiaBelanda, memerintahkan Jenderal Herman William Daendles sebagai Gubernur Jenderal Hindia-Belanda. Dalam pemerintahannya, Daendles menetapkan beberapa kebijakan terkait dengan pertanahan salah satunya menjual tanahtanah yang semula dimiliki rakyat Indonesia kepada orang-orang timur asing maupun bangsa Belanda itu sendiri. Kebijakan ini menjadi awal mula pergeseran kepemilikan hak atas tanah dari rakyat Indonesia yang disebut dengan "Inlander" 5 kepada bangsa asing.

\footnotetext{
${ }^{4}$ Urip Santoso, Hukum Agraria Kajian Komprehensif (Kencana Pranadamedia 2013).[14].

${ }^{5} \mathrm{KBBI}$ "pribumi yang pada saat penjajahan merupakan sebutan ejekan bagi penduduk asli Indonesia". <https:// kbbi.web.id/inlander> diakses 26 Juni 2019.
} 
Alfian Adam: Penerapan Asas Pemisahan...

Kemudian pada tahun 1811, Inggris memasuki wilayah Indonesia dan memenangkan perang dengan menangkap jenderal Jan Willian Janssens sehingga serta merta penguasaan Indonesia jatuh di tangan Inggris. Dalam penguasaannya, Inggris menunjuk Thomas Stamford Raffles sebagai gubernur jenderal untuk mengatur pemerintahan di Indonesia, kebijakan yang dibuat adalah sistem pajak tanah, hal ini dapat diartikan sebagai peralihan kepemilikan tanah dari raja di daerah swapraja menjadi milik raja Inggris sehingga akibat yang timbul adalah rakyat tunduk dan memiliki kewajiban memberikan pajak tanah kepada raja Inggris.

Johanes van den Bosch adalah Gubernur Jenderal Belanda pada tahun 1830, terkenal dengan kebijakan yang dikeluarkan yakni sistem tanam paksa atau cultuurstelsel. Kebijakan ini merupakan monopoli yang dilakukan oleh pemerintah Belanda dengan memaksa petani untuk menanam salah satu jenis tanaman yang dibutuhkan di pangsa pasar dunia dan hasilnya diserahkan tanpa ada imbalan. Selain penderitaan bagi rakyat Indonesia, kebijakan tersebut berimbas kepada pengusaha swasta Belanda yang merasa terbatasi modal usahanya dalam sektor pertanian. Hal ini menyebabkan pengusaha swasta mendesak untuk mendapatkan kesempatan dan kebebasan mengembangkan usahanya di sektor pertanian hingga pada tahun 1870 lahir Agrarische Wet yang memberikan jawaban atas desakan pengusaha swasta Belanda. Dalam pelaksanaannya, Agrarische Wet berhasil memberikan keuntungan bagi pengusaha Belanda, namun berbanding terbalik dengan kondisi yang dialami rakyat Indonesia atas tanah yang dimilikinya diambil alih oleh pemerintah Belanda untuk diberikan bagi kepentingan penanaman modal oleh pihak swasta.

Dalam pelaksanaan Agrarische Wet, lahir kebijakan sebagai pelaksana Agrarische Wet yaitu Agrarische Besluit. Dalam peraturan dan keputusan ini, Agrarische Besluit menyebabkan banyaknya tanah milik rakyat Indonesia yang diambil alih secara serta merta oleh pemerintahan Belanda karena pada saat itu tanah milik rakyat Indonesia tidak di landasi dengan sertifikat kepemilikan, berdasarkan pernyataan "domein verklaring" karena apabila rakyat Indonesia tidak dapat membuktikan sebagai hak eigendom-nya maka tanah tersebut 
milik negara. Posisi dominan yang dimiliki pemerintah Belanda berdasarkan "domein verklraring" mengakibatkan penggunaan dan hak-hak atas tanah untuk kepentingan pemerintah Belanda. Pada tanggal 24 September 1960, ${ }^{6}$ Agrarische Wet dan Agrarische Besluit di cabut dan dinyatakan tidak berlaku, serta aturanaturan dan kebijakan yang lahir pada zaman kolonial. Hal ini merupakan substansi keberlakuan UUPA yang tidak memberlakukan lagi atau mencabut hukum agraria kolonial. Dalam rezim pertanahan, keberadaan UUPA memberikan kepastian hukum bagi rakyat Indonesia yang pada awalnya di jadikan permainan oleh pemerintah Belanda dengan aturan-aturan hukum yang lahir pada zaman kolonial. Selain itu, maksud dan tujuan UUPA termaktub didalam konsideran menimbang, berpendapat, dan dalam penjelasan. Seiring berjalannya waktu dan perkembangan, lahir aturan-aturan pelaksana yang berkaitan dengan tanah yang diatura dalam UUPA.

Berakhirnya dualisme hukum setelah lahirnya UUPA memberikan kepastian serta perlindungan bagi Warga Negara Indonesia serta menghilangkan kesewenang-wenangan pihak manapun dalam penggunaan, pemanfaatan hingga penguasaan tanah. Seiring dengan lahirnya UUPA, konsentrasi dari unifikasi hukum agraria sendiri memberi batasan-batasan bagi orang asing untuk dapat memperoleh hak atas tanah karena tidak ingin terjebak lagi dalam upaya-upaya politik non-pribumi sehingga dapat menyebabkan ketidakstabilan negara. Dewasa ini, UUPA hanya memberikan kesempatan bagi orang asing untuk memperoleh hak atas tanah di Indonesia berupa hak pakai dengan jangka waktu yang telah ditentukan sebagaimana Pasal 41 UUPA, Peraturan Pemerintah Nomor 18 Tahun 2021 tentang Hak Pengelolaan, Hak Atas Tanah, Satuan Rumah Susun, dan Pendaftaran Tanah ${ }^{7}$ (selanjutnya disebut PP 18/2021), dan peraturan-peraturan terkait lainnya.

${ }^{6}$ Tanggal 24 September 1960 merupakan tanggal lahir Undang-Undang Republik Indonesia Nomor 5 Tahun 1960 tentang Peraturan Dasar Pokok-Pokok Agraria yang juga ditetapkan sebagai Hari Agraria Nasional.

${ }^{7}$ Peraturan Pemerintah Republik Indonesia Nomor 18 Tahun 2021 tentang Hak Pengelolaan, Hak Atas Tanah, Satuan Rumah Susun, dan Pendaftaran Tanah, Lembaran Negara Republik Indonesia Nomor 28 Tahun 2021, Tambahan Lembaran Negara Republik Indonesia Nomor 6630. 


\section{Hak atas Tanah bagi orang asing}

Hukum agraria nasional memiliki bermacam-macam hak atas tanah yang memiliki sifat berbeda-beda antara lain Hak Milik dengan sifatnya terkuat, terpenuh dan turun-temurun sehingga tidak memiliki jangka waktu, kemudian terdapat hak atas tanah yang sifatnya memiliki jangka waktu tertentu atau sementara yang diatur dalam peraturan perundang-undangan dalam rezim hukum agraria yakni Hak Guna Usaha, Hak Guna Bangunan, Hak Pakai, Hak Sewa.

Adapun maksud dan tujuan adanya pemberian jangka waktu terhadap hak-hak atas tanah untuk pemerataan penggunaan tanah itu sendiri bagi rakyat indonesia dalam menggunakan atau memanfaatkan tanah mengingat negara sebagai organisasi kekuasaan seluruh rakyat memiliki hak menguasai yang memberi wewenang antara lain :

1. Mengatur dan menyelenggarakan peruntukan, penggunaan persediaan, dan pemeliharaaan bumi, air, dan ruang angkasa tersebut;

2. Menentukan dan mengatur hubungan-hubungan hukum antara orangorang dengan bumi, air, dan ruang angkasa;

3. Menentukan dan mengatur hubungan-hubungan hukum antara orangorang dan perbuatan-perbuatan hukum yang mengenai bumi, air, dan ruang angkasa.

Wewenang tersebut diatas digunakan untuk mencapai sebesar-besar kemakmuran rakyat dalam arti kebangsaan, kesejahteraan, dan kemerdekaan dalam masyarakat dan negara hukum indonesia yang merdeka, berdaulat, adil, dan makmur.

Terdapat pepatah yang diutarakan oleh pemimpin dan politikus Romawi Julius Caesar "Experience is the teacher of all things" atau yang artinya "Pengalaman adalah guru semua hal". ${ }^{8}$ Belajar dari pengalaman, Indonesia yang telah merasakan penindasan pada era kolonial terhadap penggunaan,

${ }^{8}$ Wilma Yulia, 'Kata Mutiara Bahasa Inggris tentang Pengalaman (Experience)', (wordsmile. com, 9 Januari 2017) <https://www.wordsmile.com/kata-mutiara-bahasa-inggris-pengalamanexperience-artinya> diakses pada 28 Juni 2019. 
pemanfaatan dan pemfungsian tanah maka untuk memperoleh perlindungan hukum yang pasti perlu di bentuk aturan-aturan terkait tanah hingga lahir UUPA dan peraturan-peraturan pelaksana yang memberikan batasan-batasan bagi pihak-pihak yang boleh memperoleh hak atas tanah di Indonesia. Batasanbatasan sebagaimana dimaksud adalah syarat dan terhadap hak atas tanah apa saja yang dapat diperoleh, sebagaimana hak atas tanah yang terdapat pada Pasal 16 UUPA. Khususnya dalam penulisan Jurnal ini, akan memperhatikan batasan-batasan bagi orang asing masih dimungkinkan mendapatkan hak atas tanah di Indonesia.

Di era globalisasi ini teknologi dan industrialisasi berkembang semakin pesat, tentunya negara Indonesia sebagai negara berkembang menjadi salah satu destinasi investasi yang dilakukan oleh orang asing. Semakin terbukanya pintu masuk bagi orang asing kedalam Indonesia didasari peluang penanaman modal dalam mendirikan sebuah usaha sebagaimana Undang-undang Nomor 25 tahun 2007 tentang Penanaman Modal $^{9}$ (selanjutnya disebut UU Penanaman Modal) dan Undang-undang Nomor 40 Tahun 2007 tentang Perseroan Terbatas ${ }^{10}$ (selanjutnya disebut UU PT), oleh karenanya pemerintah sebagai representasi negara disamping marwahnya untuk membuat negara berkembang dan maju wajib memperhatikan aturan-aturan sebagai pelindung negara atas kemungkinan tindakan sewenangwenang dari orang asing yang bertujuan melakukan kunjungan hingga bahkan berbisnis dan/atau menetap di Indonesia.

Ada dua kelompok orang asing yang diperbolehkan tinggal di Indonesia, pertama adalah Orang Asing yang mendapat izin masuk (admission) dengan hak untuk tinggal di Indonesia dalam jangka waktu tertentu, kemudian yang kedua adalah Orang Asing yang diizinkan untuk tinggal di Indonesia dan memilih sebagai Penghuni atas dasar yang ditentukan atau Gevestegd. ${ }^{11}$ Namun, orang asing

\footnotetext{
${ }^{9}$ Undang-Undang Nomor 25 Tahun 2007 tentang Penanaman Modal, Lembaran Negara Nomor 67 Tahun 2007, Tambahan Lembaran Negara Nomor 4724.

${ }^{10}$ Undang-Undang Nomor 40 Tahun 2007 tentang Perseroan Terbatas, Lembaran Negara Nomor 106 Tahun 2007, Tambahan Lembaran Negara Nomor 4756. 2001).[134].

${ }^{11}$ Maria S.W. Sumardjono, Kebijakan Pertanahan Antara Regulasi dan Implementasi (Kompas
} 
Alfian Adam: Penerapan Asas Pemisahan...

tersebut harus memiliki peran penting di Indonesia dengan melakukan kegiatan ekonomi di Indonesia, oleh karena itu orang asing membutuhkan rumah tinggal atau hunian. ${ }^{12}$

Perlu diperhatikan dalam penerapan undang-undang tentang keberadaan orang asing untuk memperoleh hak atas tanah di Indonesia, harus ada kesepakatan untuk menyelundupkan undang-undang dalam banyak hal termasuk perkawinan antara orang asing dan penduduk asli Indonesia, ${ }^{13}$ atau pembelian hak atas tanah. yang dibungkus dengan perjanjian nominee. Perjanjian Nominee memuat pernyataan hubungan hukum antara warga negara Indonesia dengan orang asing yang menyatakan bahwa kepemilikan hak atas tanah tersebut pada dasarnya adalah milik warga negara Indonesia dan orang asing yang bersangkutan yang dapat memerintahkan berbagai perbuatan hukum terhadap hak-hak yang "dimiliki" oleh orang asing yang dipercaya untuk mengurusnya. itu (wali). ${ }^{14}$ Namun menurut pendapat ini, akibat hukum jika terjadi perjanjian pencalonan adalah perjanjian menjadi tidak sah karena melanggar ketentuan peraturan perundang-undangan, maka perjanjian pencalonan batal demi hukum. ${ }^{15}$

Orang asing dalam memperoleh hak atas tanah tidak terlepas dari aspek perjanjian, dimana perjanjian tersebut harus dibuat dalam bentuk akta Pejabat Pembuat Akta Tanah (PPAT) serta dicantumkan dalam buku tanah dan sertifikat hak atas tanah yang dipersyaratkan. ${ }^{16}$ Menurut ketentuan Pasal 1313 BW, perjanjian adalah suatu perbuatan dengan satu orang atau lebih yang mengikatkan diri kepada seorang atau lebih orang lain. Subyek perjanjian adalah para pihak dalam hal ini adalah orang asing dan warga negara Indonesia dengan obyek tanah dan/

\footnotetext{
${ }^{12}$ Mira Novana Ardani, 'Kepemilikan Hak Atas Tanah Bagi Orang Asing Di Indonesia' (2017) 13 Law Reform Journal.[212].

${ }^{13}$ Pasal 70 Peraturan Pemerintah Republik Indonesia Number 18 Tahun 2021 tentang Hak Pengelolaan, Hak Atas Tanah, Satuan Rumah Susun, dan Pendaftaran Tanah.

${ }^{14}$ Eddy Nyoman Winarta et al, 'Hak Pakai Atas Rumah Hunian Warga Negara Asing Dalam Perkawinan Campuran Tanpa Perjanjian Kawin' (2017) 2 Acta Comitas Jurnal Hukum Kenotariatan.[48].

${ }^{15}$ Eri Abadi Putra et al, 'Akibat Hukum Terhadap Kepemilikan Tanah di Bali Oleh Orang Asing Dengan Perjanjian Nominee’ (2016) 4 Kertha Semaya: Journal Ilmu Hukum.[5].

${ }^{16}$ Pasal 7 Peraturan Pemerintah Republik Indonesia Nomor 103 Tahun 2015 tentang Pemilikan Rumah Tempat Tinggal Atau Hunian Oleh Orang Asing Yang Berkedudukan Di Indonesia.
} 
atau bangunan diatasnya yang memerlukan peraturan perundang-undangan yang berlaku. ${ }^{17}$

Dewasa ini terhadap orang asing yang akan masuk ke Indonesia dengan tujuan wisata, menuntut ilmu pendidikan, bekerja, hingga mendirikan suatu usaha tentu membutuhkan tempat untuk ditinggali, khususnya bagi orang asing yang akan bekerja dan atau mendirikan suatu usaha yang tentutnya akan lebih lama untuk bertahan hidup di Indonesia. Halmana kebutuhan tersebut untuk tidak disalahgunakan oleh orang asing perlu dibuatkan aturan yang dapat bersinergi untuk menjamin keadilan dan kepastian hukum bagi rakyat indonesia agar tidak terulang kembali kepedihan di masa lampau mengingat muara dari adanya penjajahan tidak di mulai dari kekerasan melainkan dari tindakan halus yakni di awali keadatangan VOC guna kepentingan perdagangan. Hingga saat ini peraturan perundang-undangan yang sehubungan dengan keberadaan orang asing yang akan tinggal di Indonesia telah ter"cover" dalam UUPA dan PP 18/2021 dengan hanya memberikan peluang bagi orang asing memperoleh hak atas tanah berupa Hak Pakai, halmana dalam peraturan perundang-undangan tersebut mengatur terkait hak-hak dan kewajiban-kewajiban bagi orang asing dalam disiplin penggunaan tanah dan selain itu penulis menemukan terdapat antinomi aturan terkait jangka waktu perolehan hak atas tanah bagi orang asing (Hak Pakai) tersebut.

\section{Antinomi Jangka Waktu Hak Pakai bagi orang asing}

Hukum agraria nasional memiliki bermacam-macam hak atas tanah yang memiliki sifat berbeda-beda antara lain Hak Milik dengan sifatnya terkuat, terpenuh, dan turun-temurun sehingga tidak memiliki jangka waktu, kemudian terdapat hak atas tanah yang sifatnya memiliki jangka waktu tertentu atau sementara yang diatur dalam peraturan perundang-undangan dalam rezim hukum agraria yakni Hak Guna Usaha, Hak Guna Bangunan, Hak Pakai, Hak Sewa.

${ }^{17}$ Euginie Vita Paulina Kaseger, 'Pemilikan Hunian Oleh Warga Negara Asing Di Indonesia' (2014) 2 Lex Et Societas.[7]. 
Alfian Adam: Penerapan Asas Pemisahan...

Dewasa ini, merujuk dalam pembahasan terkait jangka waktu tertentu atau sementara khususnya Hak Pakai atas tanah bagi orang asing yang berkedudukan di Indonesia dalam perolehan rumah tempat tinggal atau hunian berdasarkan UUPA yang diatur lebih lanjut dalam PP 18/2021 yang merupakan peraturan pelaksana atas lahirnya Undang-Undang Nomor 11 Tahun 2020 tentang Cipta Kerja. ${ }^{18}$ (untuk selanjutnya disebut UU Cipta Kerja). Adapun PP 18/2021 merupakan peraturan pemerintah yang mencabut dan menyatukan dua peraturan pemerintah sebelumnya yakni Peraturan Pemerintah Nomor 40 Tahun 1996 tentang Hak Guna Usaha, Hak Guna Bangunan dan Hak Pakai atas Tanah ${ }^{19}$ (untuk selanjutnya disebut PP 40/96) dengan PP 103/2015 yang terdapat perbedaaan dan/atau pertentangan aturan jangka waktu terhadap Hak Pakai bagi orang asing pada kedua peraturan perundang-undangan tersebut, sehingga lahirnya PP 18/2021 memberikan kepastian hukum atas adanya pertentangan jangka waktu hak pakai bagi orang asing pada peraturan-peraturan perundang-undangan sebelumnya yang dapat menyebabkan timbul sengketa atas kekacauan akibat pertentangan aturan.

Namun, disamping itu, Pasal 102 PP 18/2021 semua peraturan perundangundangan yang merupakan ketentuan pelaksana dari PP 40/96 dan PP 103/2015 dinyatakan tetap berlaku sepanjang tidak bertentangan dengan ketentuan dalam PP 18/2021, maka terhadap peraturan pelaksana khususnya yakni Peraturan Menteri Agraria dan Tata Ruang/Kepala Badan Pertanahan Nasional RI Nomor 29 Tahun 2016 tentang Tata Cara Pemberian, Pelepasan, Atau Pengalihan Hak Atas Pemilikan Rumah Tempat Tinggal atau Hunian Oleh Orang Asing Yang Berkedudukan Di Indonesia ${ }^{20}$ (selanjutnya disebut Permen Agraria 29/2016) memiliki muatan aturan terkait jangka waktu Hak Pakai bagi orang asing yang

${ }^{18}$ Undang-Undang Republik Indonesia Nomor 11Tahun 2020 tentang Cipta Kerja, Lembaran Negara Republik Indonesia Nomor 245 Tahun 2020, Tambahan Lembaran Negara Republik Indonesia Nomor 6573.

${ }^{19}$ Indonesia, Peraturan Pemerintah Republik Indonesia Nomor 40 Tahun 1996 tentang Hak Guna Usaha, Hak Guna Bangunan, dan Hak Pakai Atas Tanah, Lembaran Negara Republik Indonesia Nomor 58 Tahun 1996, Tambahan Lembaran Negara Republik Indonesia Nomor 364.

${ }^{20}$ Peraturan Menteri Agraria dan Tata Ruang/Kepala Badan Pertanahan Nasional RI Nomor 29 Tahun 2016 tentang Tata Cara Pemberian, Pelepasan, Atau Pengalihan Hak Atas Pemilikan Rumah Tempat Tinggal atau Hunian Oleh Orang Asing Yang Berkedudukan Di Indonesia, Berita Negara Republik Indonesia Nomor 1442 Tahun 2016. 
bertentangan dengan PP 18/2021, oleh karenanya perlu segera dibentuk peraturan pelaksana (Peraturan Menteri) baru dan disesuaikan dengan PP 18/2021 agar dikemudian hari tidak timbul permasalahan atas adanya pertentangan aturan terkait jangka waktu Hak Pakai bagi orang asing.

Dewasa ini, mengacu pada pembahasan terkait jangka waktu tertentu atau sementara, khususnya Hak Pakai bagi orang asing yang berdomisili di Indonesia dalam perolehan rumah tinggal atau hunian berdasarkan UUPA yang diatur lebih lanjut tentang Peraturan Pemerintah Nomor 40 Tahun 1996 tentang Hak Guna Usaha, Hak Guna Bangunan dan Hak Pakai atas Tanah ${ }^{21}$ dengan PP 103/2015 bahwa terdapat perbedaan pada kedua peraturan perundang-undangan tersebut sehingga dikhawatirkan akan timbul perselisihan akibat kekacauan yang timbul dari aturan yang saling bertentangan.

Hak pakai atas tanah dalam UUPA diatur dalam Bagian VI tentang Hak Pakai Pasal 41 - Pasal 43 UUPA, berkaitan dengan jangka waktunya diatur dalam Pasal 41 Ayat (2) UUPA:

Hak pakai dapat diberikan:

a. Selama jangka watu yang tertentu atau selama tanahnya digunakan untuk keperluan tertentu;

b. Dengan Cuma-Cuma, dengan pembayaran atau pemberian jasa berupa apapun.

Dalam UUPA jangka waktu bagi Hak Pakai tidak ditentukan secara jelas dan tegas terkait berapa lama pemberian hak pakai untuk menggunakan dan memungut hasil tanah tersebut. Pasal 41 Ayat (2) UUPA ini hanya mengatur selama jangka waktu tertentu atau selama tanahnya digunakan untuk keperluan tertentu. Dalam hierarki peraturan perundang-undangan, Undang-undang Nomor 12 Tahun 2011 tentang Pembentukan Peraturan Perundang-Undangan ${ }^{22}$ (selanjutnya disebut

\footnotetext{
${ }^{21}$ Peraturan Pemerintah Republik Indonesia Nomor 40 Tahun 1996 tentang Hak Guna Usaha, Hak Guna Bangunan, dan Hak Pakai Atas Tanah, Lembaran Negara Republik Indonesia Number 58 Of 1996, Tambahan Lembaran Negara Republik Indonesia Number 3643.

${ }^{22}$ Undang-Undang Nomor 12 Tahun 2011 tentang Pembentukan Peraturan PerundangUndangan, Lembaran Negara Nomor 82 Tahun 2011, Tambahan Lembaran Negara Nomor 5234.
} 
Alfian Adam: Penerapan Asas Pemisahan...

UU PPUU), terkait Hak Pakai dalam UUPA diatur lebih lanjut dalam peraturan pelaksana. Adapun peraturan pelaksana sebagai pendukung Undang-Undang yakni salah satunya Peraturan Pemerintah, jangka waktu Hak Pakai dalam UUPA diatur lebih lanjut dalam Pasal 52 PP 18/2021 yang dibagi sesuai dengan asal tanahnya.

Jangka waktu yang diatur dalam PP 18/2021 sebagai berikut :

\begin{tabular}{|c|c|c|}
\hline $\begin{array}{l}\text { Hak Pakai atas Tanah } \\
\text { Negara }\end{array}$ & $\begin{array}{l}\text { Hak Pakai atas tanah Hak } \\
\text { Pengelolaan }\end{array}$ & $\begin{array}{l}\text { Hak Pakai atas tanah } \mathbf{H} \\
\text { Milik }\end{array}$ \\
\hline $\begin{array}{l}\text { Jangka waktu untuk perta- } \\
\text { ma kali paling lama } 30 \text { ta- } \\
\text { hun }\end{array}$ & $\begin{array}{l}\text { erta- } \\
\text { ahun }\end{array}$ & $\begin{array}{l}\text { an angka wak- } \\
30 \text { tahun }\end{array}$ \\
\hline $\begin{array}{l}\text { Dapat diperpanjang untuk } \\
\text { jangka waktu paling lama } \\
20 \text { tahun }\end{array}$ & $\begin{array}{l}\text { Dapat diperpanjang untuk } \\
\text { jangka waktu paling lama } 20 \\
\text { tahun }\end{array}$ & aran men- \\
\hline $\begin{array}{l}\text { Dapat diperbaharui untuk } \\
\text { jangka waktu paling lama } \\
30 \text { tahun }\end{array}$ & $\begin{array}{l}\text { Dapat diperbaharui untuk } \\
\text { jangka waktu paling lama } 30 \\
\text { tahun }\end{array}$ & $\begin{array}{l}\text { Dapat diperbaharui dengan } \\
\text { akta pemberian hak pakai } \\
\text { diatas tanah hak milik. }\end{array}$ \\
\hline
\end{tabular}

Terhadap masing-masing hak pakai tersebut sebagaimana ketentuan Pasal 54 ayat (1) PP 18/2021 wajib untuk didaftarkan pada Kantor Pertanahan

Adapun jangka waktu yang diberikan bagi orang asing yang mendapatkan hak pakai atas tanah dalam PP 18/2021 mengikuti sebagaimana jangka waktu Hak Pakai yang diatur dalam Pasal 52 PP 18/2021 diatas. Sedangkan dalam Permen Agraria 29/2016 memberikan jangka waktu sebagai berikut:

\begin{tabular}{|lll|}
\hline $\begin{array}{c}\text { Rumah Tempat Tinggal } \\
\text { diatas tanah hak pakai } \\
\text { atas tanah Negara }\end{array}$ & $\begin{array}{c}\text { Rumah Tempat Tinggal } \\
\text { diatas tanah hak pakai atas } \\
\text { tanah Hak Pengelolaan }\end{array}$ & $\begin{array}{c}\text { Rumah Tempat Tinggal } \\
\text { diatas tanah Hak Pakai di } \\
\text { atas Hak Milik }\end{array}$ \\
\hline Tidak diatur & Tidak diatur & $\begin{array}{c}\text { Jangka waktu untuk perta- } \\
\text { ma kali paling lama 30 (tiga } \\
\text { puluh) tahun }\end{array}$ \\
Tidak diatur & Tidak diatur & $\begin{array}{l}\text { Dapat diperpanjang untuk } \\
\text { jangka waktu paling lama }\end{array}$ \\
& & 20 (dua puluh) tahun \\
Tidak diatur & Tidak diatur & $\begin{array}{l}\text { Dapat diperbaharui untuk } \\
\text { jangka waktu paling lama } \\
\end{array}$ \\
& & 30 (tiga puluh) tahun \\
\hline
\end{tabular}

Pertentangan jangka waktu Hak Pakai bagi orang asing dalam UU PA, PP 18/2021, dengan peraturan pelaksana yang belum diperbaharui dapat menimbulkan masalah dalam penerapannya bagi orang asing untuk mendapat 
hak dalam memperoleh rumah tempat tinggal atau hunian dan/atau rumah susun. Peraturan perundang-undangan digunakan sebagai acuan pemberian hak atas tanah bagi orang asing, dalam prakteknya, peraturan yang lebih menguntungkan akan dipilih dalam pengajuan hak atas tanah, sehingga tidak menutup kemungkinan dikemudian hari dapat terjadi sengketa hak atas tanah terkait jangka waktu yang diperoleh atau diberikan. Maka langkah terbaik adalah untuk segera dibentuk peraturan pelaksana baru yang sifatnya mencabut dan menggantikan peraturan pelaksana yang tidak sesuai dengan perkembangan hukum terbaru.

Sebagai pisau analisa untuk memberikan pandangan keberlakuan peraturan perundang-undagan, sekalipun terdapat pertentangan norma hukum antara PP 18/2021 dan peraturan pelaksana sehubungan dengan jangka waktu Hak Pakai bagi orang asing, maka perlu ditetapkan norma yang mana harus diterapkan dengan menggunakan langkah penyelesaian konflik norma (Antinomy Law). Adapun tipe penyelesaian berkaitan dengan asas prefrensi hukum yakni asas Lex Superior, asas Lex Specialis dan asas Lex Posterior ${ }^{23}$ dapat diurai penjelasannya sebagai berikut:

1. Lex Superiori Derogat Legi Inferiori; Peraturan perundang-undangan yang lebih tinggi akan melumpuhkan peraturan perundang-undangan yang lebih rendah.

2. Lex Specialis Derogat legi Generali; Peraturan perundang-undangan yang khusus itu akan melumpuhkan peraturan yang umum sifatnya atau peraturan yang khususlah yang harus didahulukan.

3. Lex Posteriori Derogat Legi Priori; Peraturan perundang-undangan yang baru akan mengalahkan atau melumpuhkan peraturan yang lama.

Asas hukum merupakan sebuah pemikiran dasar yang menjadi landasan berfikir dalam menyusun atau membentuk peraturan perundang-undangan.

${ }_{23}$ Philipus M. Hadjon \& Tatiek Sri Djamiati, Argumentasi Hukum (Legal Argumentation) Legal Reasoning) Langkah-langkah Legal Problem Solving dan Penyusunan Legal Opinion (Gajah Mada University Press 2009).[31]. 
Alfian Adam: Penerapan Asas Pemisahan...

Berdasarkan pendapat Soedikno Mertokusumo, pengertian daripada norma hukum (kaedah hukum) meliputi asas-asas hukum, kaedah hukum dalam arti sempit atau nilai (norm) dan peraturan hukum konkrit. ${ }^{24}$ Selain itu, asas hukum atau prinsip hukum itu merupakan jantungnya peraturan hukum, hal ini dikarenakan prinsip hukum atau asas hukum merupakan landasan yang paling luas bagi lahirnya suatu peraturan hukum, ini berarti bahwa peraturan-peraturan hukum itu pada akhirnya bisa dikembalikan kepada asas-asas tersebut. ${ }^{25}$ Dalam hal demikian maka prinsip hukum dapat dijadikan dasar dalam pemecahan masalah karena asas atau prinsip hukum memiliki keterkaitan yang erat.

Sehingga, jika terdapat pertentangan peraturan perundang-undangan dapat merujuk dengan menggunakan asas-asas hukum guna menentukan aturan mana yang dapat diberlakukan untuk suatu permasalahan hukum. Sehingga, perbedaan aturan jangka waktu Hak Pakai dalam peraturan tersebut bagi orang asing yang berkedudukan di Indonesia dalam menentukan jangka waktu perolehan rumah tempat tinggal atau hunian yang dapat dikaji kekuatan mengikatnya menggunakan asas-asas hukum. Hierarkhi peraturan perundang-undangan berdasarkan Pasal 7 Ayat (1) UU PPUU adalah sebagai berikut:

a. Undang-Undang Dasar Negara Republik Indonesia Tahun 1945;

b. Ketetapan Majelis Permusyawaratan Rakyat;

c. Undang-Undang/ Peraturan Pemerintah Pengganti Undang-Undang;

d. Peraturan Pemerintah;

e. Peraturan Presiden;

f. Peraturan Daerah Provinsi; dan

g. Peraturan Daerah Kabupaten/Kota.

PP 18/2021 dengan peraturna pelaksananya (Permen Agraria) secara hierarkhis merupakan peraturan perundang-undangan memiliki kedudukan yang berbeda dan PP 18/2021 berada diatas Peraturan Menteri. Selain itu, keduanya tidak secara keseluruhan mengatur materi yang sama, akan tetapi memuat materi dalam pasal-pasal yang saling bertolak belakang, sehingga dalam penyelesaiannya

${ }^{24}$ Meta Suriyani, 'Pertentangan Asas Perundang-Undangan dalam Pengaturan Larangan Mobilisasi Anak Pada Kampanye Pemilu’ (2016) 13 Jurnal Konstitusi.[671].

25 ibid. 
apabila terdapat pertentangan dalam aturan tersebut dapat diselesaikan dengan asas prefrensi yakni Lex Superiori Derogat Legi Inferiori, maka PP 18/2021 yang dapat digunakan.

\section{Penerapan Asas Pemisahan Horizontal saat berakhirnya Hak Pakai}

Setelah berlakunya UUPA terjadi penggantian secara menyeluruh atas semua peraturan perundang-undangan dalam sistem hukum agraria yang semula berasal dari hukum kolonial yang terdapat dalam: pertama, Buku II Burgerlijk Wetboek sepanjang mengenai tanah dan keagrariaan dan kedua, semua peraturan pelaksana agrarian yang bersumber pada Agrarische Wet 1870, Agrarische Besluit 1870, Pasal 52 Indische Staatsregeling, serta semua pernyataan "Domein" diluar Jawa-Madura. Dalam pelaksanaannya, dasar pembentukan peraturan perundangundangan selalu memiliki norma aturan yang maknanya dalam setiap pasal dapat ditemukan asas-asas yang terkandung didalamnya yang salah satunya adalah Asas Pemisahan Horizontal.

Asas Pemisahan Horizontal memiliki pengertian bahwa bangunan dan tanaman yang ada di atas tanah bukan merupakan bagian dari tanah. Hak atas tanah tidak termasuk kepemilikan bangunan di atasnya. Bangunan, tanaman dan benda-benda lain yang berada di atas tanah adalah milik pihak yang membangun atau pemilik perkebunan, baik pihak yang memegang hak atas tanahnya sendiri maupun tidak, kecuali jika ada perjanjian sebaliknya. Kemudian perbuatan hukum mengenai tanah tidak dengan sendirinya meliputi bangunan, tanaman dan/atau benda lain yang berada di atasnya, jika tidak dinyatakan secara tegas. ${ }^{26}$ Asas pemisahan horizontal didasarkan pada Pasal 44 Ayat (1) UUPA yang mengatur bahwa seorang atau suatu badan hukum mempunyai hak sewa atas tanah, apabila ia berhak menggunakan tanah milik orang lain untuk keperluan bangunan, dengan membayar kepada pemiliknya, sejumlah uang sebagai uang sewa. Implementasi

${ }^{26}$ Betty Rubiati et. Al., 'Asas Pemisahan Horizontal Dalam Kepemilikan Hak Atas Tanah Dan Bangunan Satuan Rumah Susun Bagi Masyarakat Berpenghasilan Rendah (MBR)' (2015) 17 Sosiohumaniora.[96]. 
asas pemisahan horizontal adalah Hak Sewa Untuk Bangunan, yaitu seseorang atau badan hukum menyewa tanah Hak Milik orang lain yang kosong atau tidak ada bangunannya dengan membayar sejumlah uang sebagai uang sewa yang besarnya ditetapkan atas dasar kesepakatan, untuk jangka waktu tertentu, dan penyewa diberi hak untuk mendirikan bangunan yang digunakan untuk jangka waktu tertentu yang disepakati oleh kedua belah pihak. ${ }^{27}$ Terdapat pemisahan horizontal antara pemilik tanah dengan pemilik bangunan yaitu tanah milik pemilik tanah, sedangkan bangunan milik penyewa tanah.

Hak Pakai merupakan hak atas tanah yang sifatnya memiliki jangka waktu, sehingga dalam perolehannya melalui mekanisme permohonan hingga terdapat pemberian Hak Pakai maka Hak Pakai atas tanah akan dapat berakhir yakni dengan beberapa hal yang telah diatur dalam peraturan perundang-undangan antara lain:

1. Hak Pakai berakhir karena peralihan

Pasal 60 PP 18/2021 mengatur terkait peralihan Hak Pakai, Hak pakai dapat beralih dan dialihkan kepada pihak lain dengan mekanisme yang diperbolehkan oleh peraturan perundang-undangan adalah jual beli, tukar menukar, penyertaan dalam modal, hibah, serta pewarisan. Sebelumnya Perlu diingat terdapat beberapa Hak Pakai yang tidak dapat dialihkan karena hukum yakni, Hak Pakai yang dipunyai oleh badan hukum publik disebut Hak Pakai Publik ada right to use, yaitu menggunakannya untuk waktu yang tidak terbatas selama pelaksanaan tugas, namun tidak ada right of disposal, yang dimaksud disini adalah tidak dapat dialihkan dalam bentuk apapun kepada pihak ketiga dan juga tidak dapat dijadikan objek Hak Tanggungan. ${ }^{28}$

Peralihan Hak Pakai secara tidak langsung tidak berakhir karena Hak Pakai tersebut masih memiliki eksistensi sebagai hak atas tanah akan tetapi pemegang Hak Pakai beralih dari pemegang Hak Pakai pertama kepada Pemegang Hak Pakai selanjutnya. Sedangkan peralihan Hak Pakai secara

\footnotetext{
${ }^{27}$ Urip Santoso., Op.Cit.[65].

${ }^{28}$ Urip Santoso, Op.Cit.[126].
} 
langsung berakhir bagi pemegang Hak Pakai pertama demi hukum karena perbuatannya dalam mengalihkan Hak Pakai atas tanah tersebut.

2. Hak Pakai berakhir karena Hapus

Pasal 61 hingga Pasal 62 PP 18/2021 mengatur terkait materi hapusnya Hak Pakai, dimana Hak Pakai dapat berakhir apabila hapus sehingga bagi subyek Hak Pakai yang diatur dalam UUPA dan peraturan perundangundangan terkait Hak Pakainya berakhir jika hapus, yakni dalam hal ini berakhirnya jangka waktu dan/atau dibatalkan haknya oleh Menteri sebelum jangka waktu berakhir.

Hak Pakai merupakan salah satu hak atas tanah yang memiliki keseimbangan yang dalam perolehannya selalu terdapat berakhirnya Hak Pakai karena sifatnya yang memiliki jangka waktu. Dalam berakhirnya Hak Pakai sendiri tentu menimbulkan akibat hukum terhadap status hak atas tanah tersebut beserta bangunan dan benda-benda lain yang terdapat diatasnya. Akibat hukum berakhirnya Hak Pakai dapat perhatikan sebagai berikut:

1. Akibat hukum berakhirnya Hak Pakai karena peralihan

Peralihan Hak Pakai merupakan suatu perbuatan hukum yang bertujuan mengalihkan atau memindahkan hak dari suatu pihak ke pihak lain, dalam hal ini pemegang Hak Pakai pertama mengalihkan kepada calon pemegang Hak Pakai selanjutnya dengan cara-cara peralihan yang dapat dilakukan sesuai PP 18/2021. Tentunya dalam mekanisme peralihan hak, dalam tercapainya maksud akan lahirnya UUPA yakni kepastian hukum bagi pemegang hak atas tanah perlu dilakukan pendaftaran tanah yang mengacu terhadap peraturan mengenai Pendaftaran Tanah yang dapat ditemukan di PP 18/2021. Yang selanjutnya terhadap peralihan tersebut pemegang hak pakai berikutnya wajib mendaftarkan kepada Kantor Pertanahan setempat, maka dalam peralihan Hak Pakai, pemegang hak pertama demi hukum berakhir sebagai pemegang hak dan beralih kepada pemegang hak selanjutnya.

Isu yang timbul dalam berakhirnya Hak Pakai dengan peralihan adalah bagaimana dengan status bangunan diatasnya yang notabene dibangun oleh 
orang asing tersebut. Peralihan Hak Pakai bagi orang asing dapat terjadi karena jual-beli, tukar-menukar, penyertaan dalam modal, hibah, dan pewarisan, dalam peralihan Hak Pakai objek yang dialihkan adalah tanahnya yang berstatus Hak Pakai dan jika mengacu terhadap Asas Pemisahan Horizontal, peralihan ini hanya sebatas hak atas tanahnya saja sedangkan bangunannya berbeda karena perlu diperhatikan terlebih dahulu pemilik hak kebendaan terhadap bangunannya apakah dalam tindakan hukumnya melakukan peralihan juga serta merta mengalihkan bangunan dan bendabenda yang terdapat diatasnya, hal ini dimungkinkan karena secara normatif Hak Pakai obyeknya hanya memberikan tanah (Hak atas tanah) kepada calon pemegang Hak Pakai sehingga orang asing atas penguasaan terhadap tanah dapat melakukan pembangunan (gedung) yang mana bangunan tersebut merupakan hak kebendaan bagi orang asing tersebut akan tetapi perlu dijadikan catatan apabila bangunan tersebut merupakan hak kebendaan pemegang hak atas tanah pemberi hak pakai maka harus terlebih dahulu mendapat izin untuk dipergunakan dalam peralihan hak dan terkait dengan hak kebendaan atas bangunan tersebut tidak ikut beralih.

2. Akibat hukum berakhirnya Hak Pakai karena Hapusnya Hak

Akibat hukum hapusnya hak pakai sendiri, tanah tersebut kembali pada status hak atas tanah sebelum ditumpangi Hak Pakai. Hal ini diatur dalam Pasal 63 PP 18/2021:

(1) Hapusnya hak pakai sebagaimana dimaksud dalam pasal 61 diatas Tanah Negara mengakibatkan:

a. Tanah menjadi Tanah Negara; atau

b. Sesuai dengan amar putusan pengadilan.

(2) Tanah negara sebagaimana dimaksud pada ayat (1) huruf a, penataan kembali penggunaan, pemanfaatan, dan pemilikan selanjutnya menjadi kewenangan Menteri.

(3) Hapusnya hak pakai sebagaimana dimaksud dalam pasal 61 diatas Tanah Hak Pengelolaan mengakibatkan tanahnya kembali dalam penguasaan pemegang Hak Pengelolaan;

(4) Hapusnya hak pakai sebagaimana dimaksud dalam pasal 61 diatas Tanah Hak Milik mengakibatkan tanahnya kembali dalam ppenguasaan pemegang Hak Milik. 
Kata kunci dalam pengertian hak pakai sendiri adalah menggunakan dan/atau memungut hasil dari tanah, berkaitan dengan hapusnya hak pakai yang mengakibatkan beralihnya kembali hak atas tanah tersebut tidak menutup kemungkinan menyisakan bangunan dan/atau benda-benda milik pemegang hak pakai diatas tanah tersebut. Perlu diperhatikan dalam hal ini terdapat dua rezim hukum terhadap kasus hapusnya hak pakai yakni rezim hukum pertanahan terhadap status tanahnya dan rezim hukum perdata terkait dengan hak kebendaan terhadap status bangunan dan/atau benda-benda tersebut. Dalam penulisan di sub bab sebelumnya telah dijelaskan landasan filosofis dibentuknya UUPA yang berakar dari keinginan unifikasi hukum dari terdapatnya dualisme hukum yakni hukum agraria adat dan hukum agrarian berdasarkan hukum barat untuk mencapai kepastian hukum bagi warga negara indonesia yang sampainya telah melahirkan Peraturan Perundang-undangan agararia yang berdasarkan atas hukum adat tanah, dan terdapat asas-asas yang melekat ditiap norma aturan yang salah satunya adalah asas pemisahan horizontal yang secara tegas membedakan antara hukum yang berkaitan dengan tanah dan hukum yang berkaitan dengan bangunan dan/atau benda diatasnya.

Pasal 57 huruf e PP 18/2021 mengatur kewajiban bagi pemegang hak pakai yakni salah satunya "menyerahkan kembali Tanah yang diberikan dengan hak pakai kepada negara, pemegang hak pengelolaan, atau pemegang hak milik, setelah hak pakai hapus." Menjadi menarik saat bangunan yang dibangun oleh orang asing yang memiliki nilai ekonomis statusnya harus ikut diserahkan atau dilakukan pembongkaran atau mungkin diberi penggantian biaya sesuai dengan nilai taksasi atau kesepakatan bersama.

Dari aturan Pasal 57 huruf e PP 18/2021 perlu dimaknai bahwa akibat hukum hapusnya hak pakai, pemegang hak pakai wajib menyerahkan atau mengembalikan tanahnyA. Berkaitan dengan bangunan dan/atau benda-benda diatasnya masih diperlukan atau terdapat kesepakatan dalam perjanjian penggunaan tanah merupakan bentuk pengecualian apabila diperjanjikan lain. 
Alfian Adam: Penerapan Asas Pemisahan...

Dalam hal orang asing yang telah hapus hak pakainya serta terkait status bangunan dan/atau benda-benda diatasnya, maka iapun tunduk terhadap Pasal 57 huruf e PP 18/2021 sehingga dapat diambil pengertian sebagai berikut:

- Pasal 57 huruf e PP 18/2021, Pasal ini tidak mengatur dengan jelas status bangunan apabila Hak Pakai berakhir, hanya mengatur bahwa tanah tersebut harus diserahkan kembali. Maka dalam pengaturan terkait status bangunan dapat di jabarkan sebagai berikut:

a. Hak Pakai atas tanah Hak Pengelolaan

Dalam kesepakatan yang dituangkan dalam perjanjian penggunaan tanah terhadap tanah Hak Pengelolaan orang asing dapat memperjanjikan terkait status bangunan apabila Hak Pakai berakhir akan tetapi tanah Hak Pengelolaan merupakan aset Pemerintah Daerah maka hal ini tidak mungkin diperjanjikan terkait ganti kerugian bangunan karena pemerintah daerah dalam memberikan pemfungsian tanahnya bagi orang asing tidak ingin mendapatkan kerugian dengan memberi kompensasi terhadap bangunannya.

b. Hak Pakai atas tanah Hak Milik

Hak Pakai atas tanah Hak Milik dalam perjanjian penggunaan tanah lebih mudah untuk dimintakan ganti kerugian terkait bangunan dalam mekanisme berakhirnya Hak Pakai karena orang asing lebih mudah berkomunikasi terhadap pemegang Hak Milik untuk melahirkan kesepakatan terkait hal tersebut sehingga dapat meminta ganti kerugian di kemudian hari, akan tetapi perlu dijadikan catatan bahwa Hak Milik memiliki sifat terkuat dan terpenuh maka dalam mencapai kesepakatan perjanjian penggunaan tanah pemegang Hak Milik dapat menolak untuk memberikan ganti kerugian terhadap bangunannya yang mengakibatkan bangunan tersebut dapat serta merta dibongkar apabila Hak Pakai tersebut berakhir.

Implementasi pengembalian tanah menjadi kewajiban yang berkaitan dengan prinsip hukum agraria yakni Asas Pemisahan Horisontal oleh karenanya, frasa "pengembalian tanah" mempertegas bahwa tanah tersebut untuk dikembalikan sebagaimana mestinya sesuai pada saat tanah tersebut 
ditumpangi Hak Pakai, maka terhadap bangunan yang berada diatasnya yang dibangun oleh orang asing bukan menjadi tanggungan bagi pemegang hak atas tanah awal, namun apabila disepakati atau di perjanjikan maka bangunan tersebut dapat diberikan ganti kerugian.

\section{Kesimpulan}

Terdapat kontradiksi pengaturan terkait jangka waktu perolehan Hak Pakai atas tanah yang diatur dalam PP 40/96 dengan PP 103/2015, tetapi dalam perkembanganhukum diIndonesia terhadapkedua peraturan perundang-undangan tersebut telah dicabut dan digantikan PP 18/2021 sehingga terhadap jangka waktu pemberian Hak Pakai telah disesuaikan, namun terhadap peraturan pelaksanaan yang lama yakni Permen Agraria 29/2016 belum diubah dan disesuaikan dengan PP 18/2021 maka dapat menimbulkan kontradiksi pemberian jangka waktu, oleh karenanya patut untuk diperhatikan dan dilakukan penyesuaian dengan segera.

Dalam hal hak pakai telah berakhir maka ada kewajiban bagi orang asing untuk menyerahkan kembali tanah, dan terhadap status bangunan yang ada di atas tanah tersebut bukan menjadi kewajiban pemegang hak atas tanah awal untuk memberikan ganti kerugian, tetapi apabila diperjanjikan dan/atau dibutuhkan, terhadap bangunan tersebut orang asing di mungkinkan mendapat penggantian sesuai dengan taksasi atau nilai yang disepakati. Hal ini sesuai dengan penerapan asas pemisahan horisontal.

\section{Daftar Bacaan}

\section{Buku}

Maria S.W. Sumardjono, Kebijakan Pertanahan Antara Regulasi dan Implementasi (Kompas 2001).

Philipus M. Hadjon \& Tatiek Sri Djamiati, Argumentasi Hukum (Legal Argumentation/ Legal Reasoning) Langkah-langkah Legal Problem Solving dan Penyusunan Legal Opinion (Gajah Mada University Press 2009).

Urip Santoso, Hukum Agraria Kajian Komprehensif (Kencana Pranadamedia 2013). 


\section{Jurnal}

Betty Rubiati, Yani Pujiwati, Mulyani Djakaria, 'Asas Pemisahan Horizontal Dalam Kepemilikan Hak Atas Tanah Dan Bangunan Satuan Rumah Susun Bagi Masyarakat Berpenghasilan Rendah (MBR)', (2015) 17 Jurnal Sosiohumaniora.

Eddy Nyoman Winarta, 'Hak Pakai Atas Rumah Hunian Warga Negara Asing Dalam Perkawinan Campuran Tanpa Perjanjian Kawin' (2017) 2 Acta Comitas Jurnal Hukum.

Eri Abadi Putra et. al, 'Akibat Hukum Terhadap Kepemilikan Tanah di Bali Oleh Orang Asing Dengan Perjanjian Nominee' (2016) 4 Kertha Semaya: Journal Ilmu Hukum.

Euginie Vita Paulina Kaseger, 'Pemilikan Hunian Oleh Warga Negara Asing Di Indonesia' (2014) 2 Lex Et Societas.

Meta Suriyani, 'Pertentanganan Asas Perundang-Undangan dalam Pengaturan Larangan Mobilisasi Anak Pada Kampanye Pemilu' (2016) 13 Jurnal Konstitusi.

Mira Novana Ardani, 'Kepemilikan Hak Atas Tanah Bagi Orang Asing Di Indonesia' (2007) Law Reform Journal.

\section{Laman}

Wikipedia bahasa Indonesia, ensiklopedia bebas, 'Daftar Gubernur-Jenderal Hindia Belanda', (Wikipedia bahsa Indonesia, 7 Juni 2019), <https:// id.wikipedia.org/wiki/Daftar_Gubernur-Jenderal_Hindia_Belanda> diakses pada 26 Juni 2019.

Kamus Besar Bahasa Indonesia (KBBI), <https://kbbi.web.id/inlander> diakses 26 Juni 2019.

Wilma Yulia, 'Kata Mutiara Bahasa Inggris tentang Pengalaman (Experience)', $<$ https://www.wordsmile.com/kata-mutiara-bahasa-inggris-pengalamanexperience-artinya> diakses pada 28 Juni 2019.

\section{Perundang-undangan}

Undang-Undang Dasar Negara Republik Indonesia 1945.

Undang-Undang Republik Indonesia Nomor 5 Tahun 1960 Tentang Peraturan Dasar Pokok-Pokok Agraria, Lembaran Negara Republik Indonesia Nomor 
104 Tahun 1960, Tambahan Lembaran Negara Republik Indonesia Nomor 2043.

Undang-Undang Nomor 25 Tahun 2007 Tentang Penanaman Modal, Lembaran Negara Nomor 67 Tahun 2007, Tambahan Lembaran Negara Nomor 4724.

Undang-Undang Nomor 40 Tahun 2007 Tentang Perseroan Terbatas, Lembaran Negara Nomor 106 Tahun 2007, Tambahan Lembaran Negara Nomor 4756.

Undang-Undang Nomor 12 Tahun 2011 Tentang Pembentukan Peraturan Perundang-Undangan, Lembaran Negara Nomor 82 Tahun 2011, Tambahan Lembaran Negara Nomor 5234.

Peraturan Pemerintah Republik Indonesia Nomor 40 Tahun 1996 Tentang Hak Guna Usaha, Hak Guna Bangunan, dan Hak Pakai Atas Tanah, Lembaran Negara Republik Indonesia Nomor 58 Tahun 1996, Tambahan Lembaran Negara Republik Indonesia Nomor 3643.

Peraturan Pemerintah Nomor 24 Tahun 1997 Tentang Pendaftaran Tanah, Lembaran Negara Republik Indonesia Nomor 59 Tahun 1997, Tambahan Lembaran Negara Nomor 3696.

Peraturan Pemerintah Republik Indonesia Nomor 103 Tahun 2015 Tentang Pemilikan Rumah Tempat Tinggal Atau Hunian Oleh Orang Asing Yang Berkedudukan Di Indonesia, Lembaran Negara Republik Indonesia Nomor 325 Tahun 2015, Tambahan Lembaran Negara Republik Indonesia Nomor 5793.

Peraturan Menteri Agraria dan Tata Ruang/Kepala Badan Pertanahan Nasional Republik Indonesia Nomor 29 Tahun 2016 Tentang Tata Cara Pemberian, Pelepasan, Atau Pengalihan Hak Atas Pemilikan Rumah Tempat Tinggal atau Hunian Oleh Orang Asing Yang Berkedudukan Di Indonesia, Berita Negara Republik Indonesia Nomor 1442 Tahun 2016.

Undang-Undang Republik Indonesia Nomor 11 Tahun 2020 Tentang Cipta Kerja, Lembaran Negara Republik Indonesia Nomor 245 Tahun 2020, Tambahan Lembaran Negara Republik Indonesia Nomor 6573

Peraturan Pemerintah Republik Indonesia Nomor 40 Tahun 1996 Tentang Hak Guna Usaha, Hak Guna Bangunan, dan Hak Pakai Atas Tanah, Lembaran Negara Republik Indonesia Nomor 58 Tahun 1996, Tambahan Lembaran Negara Republik Indonesia Nomor 36.

How to cite: Alfian Adam Naafiu dan Nian Qisthi Kristalin, 'Penerapan Asas Pemisahan Horizontal Pada Hak Pakai Bagi Orang Asing di Indonesia' (2021) Vol. 4 No. 3 Media Iuris. 
--Halaman ini sengaja dibiarkan kosong-- 